Information for citation:

Podgórska-Rykała J., Kępa M. A Foundation as a Legal Institution under Polish Law. Vestnik Permskogo universiteta. Juridicheskie nauki - Perm University Herald. Juridical Sciences. 2021. Issue 54. Pp. $790-801$. (In Eng.). DOI: 10.17072/1995-4190-2021-54-790-801.

Podgórska-Rykała J., Keра M. A Foundation as a Legal Institution under Polish Law // Вестник Пермского университета. Юридические науки. 2021. Вып. 54. С. 790-801. DOI: 10.17072/1995-4190-2021-54-790-801.

UDC 340.5

DOI: $10.17072 / 1995-4190-2021-54-790-801$

\title{
A FOUNDATION AS A LEGAL INSTITUTION UNDER POLISH LAW
}

\section{Podgórska-Rykała J.}

Pedagogical University of Krakow

E-mail: joanna.podgorska-rykala@up.krakow.pl

\section{Kępa M.}

Pedagogical University of Krakow

E-mail: marcin.kepa@up.krakow.pl

\section{Received 30.05.2021}

Introduction: Introduction: foundations, although categorized by Polish law as 'typical' non-governmental organizations, are, however, entities which must be treated more widely. On the one hand, they are relatively autonomous from the state, instituted at grassroots level, and characterized by voluntary participation. On the other hand, their existence is inseparably related to the realization of socially and economically useful objectives - those firmly embedded in the objectives of the state. This makes foundations the entities which are difficult to expressly categorize. Purpose: the article aims to characterize the current state of the institution of a foundation as established in Polish legislation based on the rules of Polish law and statistical data related to the selected aspects of the functioning of foundations in Poland. We focus on four constitutive features inherent in the current concept of a foundation: legal personality; qualification as a corporate legal entity; the presence of a purpose, assets and an appropriate organizational structure, all these enabling the fulfilment of the founder's will; exclusively socially or economically beneficial goals being set and pursued. Methods: as the study mainly lies in the legal field, the primary research method used was legal analysis. Apart from that, we also relied on the methods of political science and administrative studies, thus the research is interdisiplinary in nature. Results: the interdisciplinary analysis of the institution of a foundation in Poland is embedded in the broad discussion related to the framework of the functioning of such types of institutions within the state and civil society. Research findings include the identification of the barriers to the functioning of foundations and to the development of this legal institution in Poland, as well as the identification of its main strengths and weaknesses. Conclusions: the equivocality of the institution of a foundation makes it an interesting and challenging research object, which cannot be analyzed without interdisciplinary methodology being applied - comprising not only legal analysis but also other methods centered on the study of practical issues related to the activities of non-governmental organizations of various types. The topic discussed in this paper is not sufficiently explored yet in professional literature, thus this study enables further in-depth research, including studies from the comparative perspective. The article is not comparative in nature; however, it may constitute an important voice in the ongoing discussion.

Keywords: foundation; non-governmental organization; Polish law; non-profit sector

(C) Podgórska-Rykała J., Kępa M., 2021 


\section{Information in Russian \\ ФОНД КАК ПРАВОВОЙ ИНСТИТУТ \\ В РАМКАХ ПОЛЬСКОГО ЗАКОНОДАТЕЛЬСТВА}

\section{И. Подгорска-Рыкала}

Краковский педагогический университет

E-mail: joanna.podgorska-rykala@up.krakow.pl

\section{М. Кемпа}

Краковский педагогический университет

E-mail: marcin.kepa@up.krakow.pl

\section{Поступила в редакцию 30.05.2021}

Введение: согласно польскому законодательству, фонды относятся к разряду 'типичных' неправительственных организаций, однако сущзность этого института должна трактоваться более широко. С одной стороны, фонды относительно автономны от государства, создаются по инициативе снизу, участие в их деятельности является добровольным. С другой сторонь, функционирование этих организаций неразрывно связано с реализацией общественно-полезных и экономически-ориентированных задач - тех самых, которые составляют зону ответственности самого государства. Все это несколько затрудняет однозначную интерпретацию понятия фонда. Цель: сформировать представление о фонде как правовом институте польского законодательства, опираясь на положения польского закона и статистические данные, касаюшиеся отдельных аспектов деятельности фондов на территории Польши. Акиент делается на четыре базовые характеристики, присущие правовому понятию фонда: правосубъектность; квалификация фонда как юридического субъекта корпоративного уровня; наличие иели, средств и соответствующей организационной структуры, позволяющих осуществлять волю учредителя фонда; деятельность исключительно в рамках достижения общественно-полезных и экономическиориентированных задач. Методы: исследование носит междисциплинарный характер, в работе применялись методы разных дисциплин: основная часть исследования базировалась на правовом анализе, также были задействованы методы политических и управленческих наук. Результаты: междицсиплинарный анализ фонда как правового института польского законодательства представлен как часть широкомасштабной дискуссии касательно основ функиионирования подобного рода институтов в государстве и гражданском обществе. В ходе исследования были выявлены существующие в Польше барьеры для деятельности фондов и дальнейшего развития рассматриваемого института, а также сформулированы его основные сильные и слабые стороны. Заключение: неоднозначность понятия фонда как правового института делает его интересным и перспективным объектом исследования, который требует применения междисииплинарной методологии, включающей не только правовой анализ, но и другие методы, ориентированные на изучение практических вопросов, связанных с деятельностью неправительственных организаций различных типов. Поднятая в данной статье тема пока недостаточно освещена в литературе, и наша работа открывает перспективы для дальнейших, более углубленных, в том числе сравнительных, исследований.

Ключевые слова: фонд; неправительственная организация; некоммерческая организация; польское законодательство; некоммерческий сектор; третий сектор

\section{Introduction}

Foundations, although categorized by Polish law as 'typical' non-governmental organizations, are, however, entities that must be treated widely. On the one hand, these are structures relatively autonomous from the state, instituted at grassroots and characterized by voluntary participation. On the other hand, their functioning is inseparably related with the realization of socially and economically useful objectives - those strictly embedded in the objectives of state actions. This makes foundations the entities which are difficult 
to expressly categorize and thus to analyze or even describe. The equivocality of the institution of a foundation makes it an interesting and challenging research subject, which cannot be analyzed without the interdisciplinary standpoint comprising not only legal analysis but also other methods focused on the study of practical areas related to the activity of non-governmental organizations.

The purpose of this article is to provide characterization of the institution of a foundation based on Polish legal provisions and statistical data related to the selected aspects of the functioning of foundations in Poland. We identify four features of the current legal concept of a foundation: it possesses legal personality; it is qualified as a legal entity of the corporate level; it has a purpose, property and relevant organizational structure that, taken together, enable it to fulfil the will of the founder; it is oriented toward only socially or economically useful objectives.

Being focused on the declared topic, the article constitutes an attempt to analyze the selected features and legal regulations governing the Polish institution of a foundation, as well as the most significant barriers faced by foundations functioning in Poland.

\section{The Origins of the Legal Institution of a Foundation}

Roman law knew two types of foundations: dependent and independent ones. The first institutional form with features typical of a foundation was the so-called dependent fiduciary foundation (maintenance institutions) - initially a natural person could not set up a foundation possessing property. Independent foundations set up by individuals ad pias causas started to appear in the Christian era [11, p. 113]. Assets belonging to pia causa were under a special protection of the Justinian Code (in particular its sections governing disposing and purahcasing of goods) because Justinian, aiming to preserve assets of foundations, forbade not only sale of immovable property but also donations, exchanges, the institution of perpetual lease and lien [12, p. 32].

The concept of a foundation as an activity of charitable nature initiated by the will of its founder was developed only in the period of early Middle Ages. Due to the activity of Chris- tian Church, it started to be identified with property allocated at will of the founder for the purpose indicated in the founding act [7, p. 9]. In Poland foundations appeared in the 12th and 13 th centuries. Initially they were oriented towards the activity for the benefit of the poor, however, their objectives evolved with time. The examples from that time mainly comprise hospital activity: Maltese hospital founded in 11701180 in Poznań, hospitals founded by the Order of the Knights of St. John of Jerusalem in 12001220 in Kraków and in 1214 in Wrocław. The history of a foundation as a legal institution is related with the tradition of donating to the Church [1, p. 14]. It originated from faith and Christian doctrine, centered around mercy to a fellow man, which is related, among other things, with almsgiving to the poor and providing them with other assistance as a condition for salvation after death. Later, foundations were formed not only by orders but also by laypersons. The founding of the Zamoyski Academy by Jan Zamoyski in 1591-1601 is an example of a university foundation. In the 17 th century the first scholarship foundations started to appear (the University of Kraków), there were also other types of foundations oriented towards nonChurch purposes. A good example of those could be the so-called 'dowry foundations' which were financing dowries for unmarried women. In the cultural reality of that period, having a dowry was a necessary condition for getting married $[10$, p. 359]. Lack of social security, which in its developed form was only brought by the 19th20th centuries, led to the development of foundations in segments relevant to the activities of such type.

In contemporary legislation the activities of social nature are one of the most basic legal tasks of the state and local governments, as well as invariably - non-governmental institutions of the so-called third sector. During the period until the Partitions, the foundation activity in Poland was also developing in the sector of social policy, which may be exemplified by the Priest Gabriel Boudain's Home, founded in Warsaw in 1732 based on the French model of St. Vincent de Paul's Home for Outcasts and regarded as the first Polish orphanage; and in the field of cultural policy, an example of which is the Załuski 
Library founded around 1780 in Warsaw [8, p. 11]. The ambition of one of the founders of the latter was to collect all known books within one library as it was thought that only future may estimate the true worth of prints and manuscripts [5, p. 32].

In the second half of the 18th century, in order to limit the so-called dead hand casus, there were introduced regulations hindering the takeover of real estate by the church, as canon law opposed the re-granting of land seized by church and used for non-religious purposes (church law knew no such legal institution). Hence, as opposed to secular foundations, church foundations required the consent of the state authorities for their establishment. During the period of Partitions, foundation law was developing in accordance with the adopted normative models of the occupying states: Prussian, Austrian and Russian models, respectively - depending on the district. No exceptions were established by law in this respect. After Poland regained its independence in 1918, the law of the occupying states was gradually replaced with Polish law. Among other spheres, legislative changes were to cover institutions of the third sector, including foundations.

Decree of February 7, 1919 on Foundations and Approval of Donations and Legacies ${ }^{1}$ was one of the first legislative initiatives of the new state. In the 1930s a bill on foundations was prepared, however, due to the outbreak of the Second World War, it has never come into force. Subsequently, pursuant to Decree of April 24, 1952 on Abolition of Foundations ${ }^{2}$, all existing foundations were abolished regardless of their nature as well as constitutional provisions and the content of foundation acts, which meant that since the effective date all foundations ceased to exist, and they were no longer entitled to function. Currently effective regulations governing the institution of a foundation in Poland were introduced by $A c t$ on Foundations of April 6, $1984 .^{3}$

\footnotetext{
${ }^{1}$ Decree of February 7, 1919 on Foundations and Approval of Donations and Legacies. The Journal of Laws of the Republic of Poland.1919. No. 15. Item 215.

${ }^{2}$ Decree of April 24, 1952 on Abolition of Foundations. The Journal of Laws of the Republic of Poland. 1952. No. 25. Item 172.

${ }^{3}$ Act of April 6, 1984 on Foundations: Consolidated text. The Journal of Laws of the Republic of Poland. 2020. Item 2167.
}

\section{A Foundation as a Non-Governmental Organization Under Polish Law}

The basic legal act governing the issues of foundations in Poland and being of a primary nature in relation to the Act on Foundations of April 6, 1984 is the Constitution of the Republic of Poland of April 2, 1997 4 . It is important that the Basic Law refers directly to foundations. According to Article 12 of the Constitution, the Republic of Poland shall ensure freedom for the creation and functioning of trade unions, socio-occupational organizations of farmers, societies, citizens' movements, other voluntary associations, and foundations. Article 13 prohibits political parties and other organizations whose programs are based upon totalitarian methods and the modes of activity of Nazism, fascism, and communism, as well as those whose programs or activities sanction racial or national hatred, the application of violence in order to obtain power or to influence the state policy or provide for the secrecy of their own structure or membership. In turn, Article 58(1) guarantees freedom of association to everyone. These provisions constitute a fundamental guarantee of the principle of freedom of civil society in a democratic state $[3 ; 4]$.

Act of April 23, 2003 on Public Benefit and Volunteer Work ${ }^{5}$ is the primary one among legal acts governing the issues related to the functioning of foundations and non-governmental organizations in Poland that systematizes regulatory affairs connected with the principles of conduct of public benefit activity by non-governmental organizations in the sector of public services, defines its forms and specific conditions of cooperation between public administration authorities and non-governmental organizations as well as the principles of formation and functioning of the council for public benefit work. In accordance with the Act, non-governmental organizations, including foundations and associations, shall meet the following requirements: they are established in the form of legal persons or organizational units having no legal personality but granted legal

\footnotetext{
${ }^{4}$ The Constitution of the Republic of Poland of April 2, 1997. The Journal of Laws of the Republic of Poland. 1997. No. 78. Item 483.

${ }^{5}$ Act of Law of April 24, 2003 on Public Benefit and Volunteer Work: Consolidated text. The Journal of Laws of the Republic of Poland. 2020. Item 1057.
} 
capacity by a separate act; these cannot be entities operating in the public finance sector, research institutes, banks and commercial law companies that are state or local government legal persons; they cannot work for profit. Item 3 of Article 3 additionally indicates the so-called 'other entities', which do not fall under the definition of the non-governmental organization but also run public benefit activities. These include, among others, church organizations and religious associations, associations of local government units, social cooperatives, sports clubs.

The legal acts that must be referred to when speaking of the regulations governing the operation of foundations are the already mentioned $A c t$ on Foundations of April 6, $1984^{1}$ and the Associations Act of April 7, 1989. ${ }^{2}$ The regulations included in these acts cover, among other things, the objectives of foundations and associations, the procedure for their formation and liquidation, the necessary content of statues, the register which they need to comply with, the governing bodies of these organizations, the issues concerning the conduct of business activity, the supervisory authorities over these organizations, and many other issues related to the functioning of foundations and associations.

\section{The Legal Basis of the Functioning of Foundations in Poland}

The Act on Foundations has a hybrid (mixed) design, with a clear predominance of civil law regulations over administrative law (public law) ones. De lege lata, the act does not contain a legal definition of a foundation - similar legal solutions were applied in the interwar period (Decree of February 7, 1919 on Foundations and Approval of Donations and Legacies ${ }^{3}$ ). Lack of legal definitions of foundations is a characteristic feature of many legislations [2, p. 19]. In the absence of a legal definition in a legal act, the characteristic features of a foundation must be interpreted from the text of the entire act. This approach to treating

\footnotetext{
${ }^{1}$ Act of April 6, 1984 on Foundations: Consolidated text. The Journal of Laws of the Republic of Poland. 2020. Item 2167.

${ }^{2}$ Parliamentary Act of April 7, 1989. Law on Associations: Consolidated text. The Journal of Laws of the Republic of Poland. 2019. Item 713.

${ }^{3}$ Decree of February 7, 1919 on Foundations and Approval of Donations and Legacies. Journal of Laws of the Republic of Poland. 1919. No.15. Item 215.
}

legal concepts does not raise a dispute in legal doctrine. Four elements are commonly regarded as the constituent features of a foundation. Firstly, a foundation possesses legal personality as a sui generis condition. Secondly, due to their specific organizational structure (i.e. their being legal entities of the corporate type), foundations are distinguished from, for example, cooperatives, whose substrate is an individual. The basic substrate of a foundation is assets/property. Foundations have destinataries (beneficiaries), not members. One may not obtain a membership in a foundation but may become its user. Thirdly, having a purpose, assets and an appropriate organizational structure, foundations are capable of fulfiling the will of the founder. And last but not least, foundations pursue only socially or economically useful purposes [2, pp. 27-28].

In accordance with the Act on Foundations, a foundation may be constituted for the realization of socially and economically useful objectives, in particular such as: health protection, development of economy and science, education and upbringing, art and culture, social care and assistance, environmental protection and preservation of historical monuments - provided all those are consistent with the fundamental interests of the Republic of Poland. The Act on Public Benefit and Volunteer Work provides a more complete picture of the activities that foundations can engage in. According to this act, non-governmental organizations, including foundations, may run public benefit activities, i.e. socially useful activities within the following fields:

- social assistance, including aid offered to disadvantaged families and individuals, activities aimed at ensuring equal opportunities;

- support for the family and the fostering system;

- provision of free legal aid and activities aimed at increasing the legal awareness of society;

- activities promoting professional and social integration and reintegration of individuals threatened with social exclusion;

- charity;

- activities aimed at maintaining and popularizing national traditions, cherishing the Polish identity and development of national, civil, and cultural awareness; 
- activities to support national and ethnic minorities and regional languages;

- activities aimed at integration of foreigners;

- protection and promotion of health, including medical activity;

- activities for the benefit of disabled people;

- promotion of employment and employment support policy for people remaining unemployed and at risk of redundancy;

- promotion of equal rights of men and women;

- activities for the benefit of retired people;

- activities supporting economic development, including the development of entrepreneurship;

- activities supporting the development of technology, inventiveness, and innovativeness, as well as the popularization and introduction of new technical solutions in economic practice;

- activities supporting the development of communities, including local communities;

- science, higher education, education and upbringing;

- activities for children and young people, including recreation;

- culture, art, protection of heritage and cultural assets;

- support and popularization of physical education;

- ecology and animal protection as well as the protection of natural heritage;

- tourism, cultural and regional studies;

- public order and safety;

- national defense and the activity of the Armed Forced of the Republic of Poland;

- popularization and protection of freedom and human rights as well as civil liberty, activities promoting the development of democracy;

- free civic counselling;

- life-saving and protection of population;

- aid for victims of calamities, natural disasters, armed conflicts, and wars nationally and abroad;

- popularization and protection of consumers' rights;

- activities aimed at promoting European integration and developing contacts and cooperation between/among societies;
- promotion and organization of voluntary work;

- aid for Polish diaspora and the Poles abroad;

- activities for the benefit of combatants and victims of repressions;

- activities in support of veterans, including disadvantaged ones;

- promotion of the Republic of Poland abroad;

- activity in support of family, maternity, parenthood, popularization and protection of children's rights;

- prevention of addictions and social pathologies;

- revitalization of degraded areas of cities and other settlements;

- activity in support of non-governmental organizations.

Additional tasks within the scope other than the listed, guided by their particular social utility and the possibility of their implementation by non-governmental organizations, may be defined by the Council of Ministers by way of a regulation. The provisions of the act indicate the public tasks that are desirable from the point of view of the state, those constituting, in the opinion of the legislator, the natural area of intersectoral cooperation. Foundations may conduct any activity of a charitable nature as long as it does not contradict the will of the founder. The governing board of a foundation cannot pursue its own goals, which would mean changing the founder's will. The areas of the activity of foundations indicated in the law are so extensive that they may comprise numerous specific tasks, these being explicitly or implicitly expressed in the law [3;4].

According to the very idea and essence of a foundation, its founder is a so-called benefactor, or benefactors, who can be a natural person regardless of their citizenship and place of residence or a legal person having their seats in Poland or abroad. The Act on Foundations allows foundations to be established in the territory of Poland not only by natural persons with Polish citizenship but also by foreigners. There are no restrictions with respect to the place of residence. A foundation in the territory of Poland may be established by a foreigner permanently living outside of Poland. The very seat of a foundation 
should be within the territory of the country, with a stipulation that if a foundation is to run its activity only within one province, it should have its seat in that province only [3].

In order to establish a foundation in Poland, it is necessary to make a declaration of will of the founder in the form of a notarial deed, containing a clear indication of the purpose of the foundation and the assets allocated for achieving this purpose. An exception is a foundation established in a last will (testament), in which case the form of a notarial deed is not required. A foundation established in a last will by the testator may be an heir if it is entered in the register within two years from the announcement of the last will (testament). Organizational units not possessing legal personality cannot be founders of a foundation. Commercial partnerships (a general partnership, a professional partnership, a limited partnership, or a limited joint-stock partnership) also cannot act as founders, and neither can other entities set up under civil law that possess legal capacity but do not possess legal personality (e.g. a housing community). In addition, a foundation may be set up by one or more natural persons, as well as by one or more legal persons. It seems that nothing prevents a founder from being both a natural person and a legal person concurrently, namely, by jointly expressing it via a consensual declaration of intent in the foundation act.

The Supreme Court emphasizes the duality of the declaration of will in the process of establishing a foundation: the foundation act and the statute are both necessary documents in this process; taken together, they are perceived as necessary elements affecting the normative shape of a foundation ${ }^{1}$. The foundation act has the characteristic of not being subject to change due to its unilateral legal act and personal nature, while the statute is an internal act of the foundation of private legal nature. A foundation acts based on its own statute in which the founder personally, or by means of the natural or legal persons authorized by him/her, specifies its name, seat and property, objectives, principles, forms and scope of activity, a composition and structure of its management, the appointment procedure, obligations and entitlements of this

\footnotetext{
${ }^{1}$ The Supreme Court resolution III CZP 114/06 of November
} 24, 2006. Legalis. No. 78838. body and its members. This document may also regulate the issues related to the conduct of business activity by the foundation, which is permitted, but only to the extent that serves the fulfilment of the foundation's objectives. Furthermore, a statute may regulate the admissibility and conditions of a potential merger with another foundation, changes to the organization's purpose or statute itself, as well as it may provide for the formation of other management bodies of the foundation, apart from the governing board. It is worth mentioning, however, that a statute is not the articles of association, but rather a collection of objective legal norms $[6, p$. 6]. It is also noteworthy that a statute does not constitute a source of generally applicable law nationwide [5].

There should be a reasonable balance between the purpose of the foundation and its assets. The founder is supposed to secure the source (sources) of funding the foundation and its activities if the foundation is to function as a viable legal entity. It should be remembered that in essence a foundation is property, a legal person of the corporate level, which, unlike, for example, associations, cannot rely on the work of its members. Hence, the situation of a foundation is basically determined by the assets secured (transferred, donated) by the founder. The law specifies the following as property assets of a foundation: money, securities, movable and immovable property provided for the possession of the foundation. If a foundation runs a business activity, the value of its property assets intended for this business activity cannot be lower than one thousand zloty. ${ }^{2}$ There is no obstcale for the original assets transferred by the founder into the ownership of the foundation under the foundation act to be multiplied through the efficient operation of the foundation management as long as the purpose of the foundation has not been achieved through the consumption of the original assets. It must also be remembered that what determines the existence / nonexistence of a foundation is the fulfilment of its purpose. If the declared goal is achieved, the foundation is subject to dissolution even though it may still hold considerable assets. These, in turn,

\footnotetext{
${ }^{2}$ The judgment of the Supreme Administrative Court (Pol. NSA) IV SA $1349 / 97$ of October 13, 1999. Legalis. No. 178897.
} 
will then be disposed of according to the provisions of the law. To avoid this situation, a general objective can be indicated.

The only obligatory body in a foundation is its governing board, responsible for operating the foundation's activity and representing the foundation before third parties. The Act on Foundations does not directly regulate the composition and structure of the governing board, nor does it regulate the procedure for appointing members of the governing board, leaving this to be specified in the statute. The governing board of a foundation should consist of natural persons. The legal mandate to form the board is attributed to the founder and they (the founder or the founders) usually take a decision about the first composition of the board. It must be emphasized that, by virtue of law, some persons cannot combine the participation in the foundation management with the practised profession (office, occupation, etc.) Law knows many types of such conflicts [3]. Serving as a member of the governing board may be unpaid (honorary) or renumerated (under a contract). In practice, the following contracts are concluded with the board members: employment contracts, mandate contracts, or innominate contracts. The conclusion of an employment contract or any other contract is secondary to the organizational relationship between the board member and the foundation as these contracts create a parallel contractual relationship. This correlation cannot be reversed: it is not possible to acquire the status of a member of the governing board as a result of the conclusion of contractual agreements, the only way to gain it is through an appropriate act - appointment, election, designation, etc.

To function properly, a foundation is subject to a mandatory entry in the National Court Register. The court examines if the purpose and the statute of the foundation are compliant with the regulations of law. Once the entry is registered, a foundation obtains its legal personality. Each change in the statute requires a new entry in the National Court Register. Each foundation shall report annually on its activities to the relevant Minister, which is to be done in accordance with the model provided in relevant regulations. This is aimed at verifying whether it appropriately achieves the objectives specified in the statute. The report is subject to public access. If there are doubts regarding the appropriateness of the foundation's activities, competent bodies may adequately intervene. The relevant minister or starosta (district governor) may request the court to overturn a resolution of the governing board that is in direct contradiction with the aims of the foundation or the law. The authorized body may also apply to the court to suspend the execution of the resolution until the adjudication of the case. Moreover, in the event that the management has taken an action that significantly violates regulations of law or the provisions of the statute, the competent body may set a deadline for the violation to be remedied or demand the change of the foundation's management. In case of ineffectiveness of this intervention, the competent authority is entitled to apply to the court to suspend the foundation's governing board and to appoint a compulsory administrator.

The idea of supervision over foundations dates back to the Roman Empire, and specifically to the reign of Justinian [9, p. 331]. Currently, the issue of supervision constitutes, on the one hand, the key and, on the other hand, still vague part of foundation law - both in Poland and in Western Europe [2, p. 19]. This results from the need to balance institutionally different factors in the functioning of foundations. These are, on the one hand, the interest of the state, understood first of all as the principle of compliance with the law established by competent public authorities, and, on the other hand, the autonomy of foundations, with their legal and organizational position confirmed and consolidated over the centuries [3].

When a foundation achieves the goal it was established for, or if its funds and property are exhausted, the foundation is subject to liquidation in the way specified in its statute. If the statute does not provide any rules concerning liquidation of the foundation, the relevant minister or starosta applies to the court for such liquidation. The assets of a liquidated foundation shall be allocated in accordance with the provisions of the statute or, in the absence of the relevant provisions, the court shall decide on their allocation. 


\section{The Activity of Foundations in Poland in Numbers and the Diagnosed Development Barriers}

According to the data from the Polish Central Statistical Office, in 2018 there were 101 thousand registered non-profit organizations operating in Poland ${ }^{1}$.

Associations and similar social organizations, numbering 69.1 thousand entities, constitute the most numerous group among non-profit organizations in the country $(68.4 \%$ of all such organizations), followed by foundations -14.5 thousand (14.4\%), and trade unions - 12.5 thousand $(12.4 \%)$. In addition, there are 2.7 thousand active organizations of business self-government and professional self-government, and also 1.8 thousand social religious entities $(2.6 \%$ and $1.8 \%$, respectively). Employers' organizations ( 0.3 thousand) and political parties ( 0.1 thousand) are the least in number. 87.3 thousand of the registered non-profit organizations belong to the sector of the so-called social economy, 9.3 thousand have the status of public benefit institutions, and 0.2 thousand are on the list of social enterprises. Apart from the registered organizations, there are less formalized units functioning in the non-profit sector, e.g. 5.9 thousand ordinary associations, which are registered by district starostas based on a simplified procedure, or 65.5 thousand parish organizations of the Catholic Church. In total, if we take into account the two indicated types of unregistered entities, the number of entities within the non-profit sector increases to approximately 172.4 thousand entities.

In 2018 sport, tourism, recreation, hobby $(30.6 \%)$ were the most popular areas of activity of non-profit organizations in Poland. Art and culture were indicated as the main areas of the conducted activity by $12.6 \%$ of the organizations, followed by education, upbringing, and scientific research $(9.8 \%)$, and social and humanitarian aid (7.3\%). The overwhelming majority of organizations conduct their activity directly for the benefit of natural persons $(90.4 \%)$. The dominant form of activity aimed at individual beneficiaries is organization of leisure and recreation $(70.8 \%)$.

\footnotetext{
${ }^{1}$ All statistical data quoted in this paper originate from the most up-to-date analysis of the Polish Central Statistical Office: Sektor non-profit w 2018 roku [ Non-profit sector in 2018]. GUS. Warsaw, Kraków. 2020.
}

The most frequently declared group of individual recipients covered by direct and systematic actions are children and adolescents $(52.9 \%)$.

As far as foundations alone are concerned, over $1 / 4$ of them systematically provide srvices and activities for people with disabilities, and almost $1 / 4$ - for elderly people. Around one in ten entities runs activities for the benefit of dependents, chronically or incurably ill persons $(11.4 \%)$, or for the benefit of children and young peopl from environments threatened with social exclusion $(10.3 \%)$, or for the benefit of the poor $(9.3 \%)$. On the one hand, over half of foundations focus on activities targeted at individuals, on the other, as many as $29.8 \%$ operate both for individual beneficiaries and other organizations, institutions or companies, and this is the highest percentage in the whole analyzed group of Polish non-profit organizations.

Although the number of non-governmental organizations in Poland is growing from year to year, as many as $67.3 \%$ of the organizations report various difficulties. What appers to be the key problem is raising funds for running statutory activity ( $40.4 \%$ of the organizations claim this to be a major problem). It should be noted at this point that for years the Polish NGO sector has been characterized by a significant economic stratification among its entities. The scale of the phenomenon is indicated, on the one hand, by considerable differences between the average and median values of the revenues and, on the other hand, by a small share of entities generating revenues that exceed 1 million PLN - these constitute only $5.2 \%$ of the entities belonging to the group, though generating $75.7 \%$ of the revenues of the entire sector. The effect is that the biggest and most popular organizations consume funds intended for the entire third sector, thus hindering the development of other, smaller and more local, entities. It is noteworthy that foundations, compared to associations, are characterized in Poland by a higher share of entities founded by the commercial sector ( $3.4 \%$ versus $0.4 \%$ ). Most often such foundations specialize in health protection $(16.9 \%$ of the organizations), followed by education and upbringing, research activity (15.6\%), social care and humanitarian aid (12.9\%). Compared to associations and similar social organizations, foundations also more frequently charge for the services 
they provide as part of their activities. They also stand out among other organizations as showing high percentage numbers when it comes to the conduct of business activity apart from the main non-profit activity $(11.8 \%$ of all foundations do that) or the conduct of both paid statutory activity and business activity $(6.3 \%)$.

Lack of sufficient number of people willing to be engaged in community service is the second problem indicated by non-profit organizations, including foundations $(29.6 \%$ of the organizations report this problem). It should be emphasized that only slightly over $24 \%$ of foundations use full-time employees in their work. On average, they employ 10 people (median -3 ). Employees with disabilities constitute $5.8 \%$ of people working in non-profit organizations in total, which is a higher percentage than the analogous share in national economy (3.6\%). What is more, according to statistics, the average number of active members of a foundation amounts to only 5 people (median -4$)$. This fact is directly related to the legal construction of a foundation: it is property, and what results from the legal construct of a foundation is that it has no 'members', but only users. For comparison, it should be indicated that the average number of members of other non-profit organizations is as large as 107 people (median - 24). The difference is enormous. It is worth mentioning here that foundations, unlike other entities of the third sector, often act nationwide (over $1 / 3$ of all foundations), whereas, for example, associations or religious organizations are centred rather on their activity in a specific commune, county, or province. Loose connection of foundations with the local community may be the reason for the lack of citizens' involvement in their activity. It is, however, gratifying that almost $80 \%$ of the existing foundations benefit to a varying extent from voluntary work.

One more essential feature we should mention is that foundations in Poland are rather shortlived - the mean period of their activity generally (in $60.6 \%$ of cases) amounts to $2-10$ years. Only $7.3 \%$ of foundations have been functioning for 20 years or more, whereas in the group of all nonprofit organizations, there are as many as $27.7 \%$ of entities with such a long experience. These numbers point to the instability of foundations, which may be determined by numerous reasons of various nature. It appears to be closely related to the third barrier to the development of the nonprofit sector in Poland, namely the problems resulting from legal regulations and procedures ( $22 \%$ of foundations report this problem as being essential). Although, as pointed out in the first part of the article, the regulations governing the establishment and functioning of foundations in Poland are relatively stable (the main Act in this field dates back to 1984), and despite their merely general framework character, the very legal structure of a foundation and its interrelationship with other legal institutions may cause - and, as it turns out, does cause - a number of doubts and practical difficulties.

\section{Conclusions}

The Polish institution of a foundation characterized in the article is an example of a nongovernmental organization with specific features. Four features are worth pointing out as constituting the legal structure of the foundation and determining its role in the legal system. These are: legal personality, qualification of the foundation as a corporate legal entity, the presence of a purpose, assets and an organizational structure enabling the implementation of the founder's will, and, finally, exclusively socially or economically beneficial goals being pursued. Each of the features is connected with a number of research and interpretation problems, which have been indicated by the authors in the text; however, the solution of those was not the aim of the article. The authors hope that their reflections on the topic may constitute an important voice in the academic discussion, thus enabling further comparative research.

The analysis of legal bases underlying the regulation of the institution of a foundation in Poland allows us to draw several general conclusions. First of all, the fact that the Act on Foundations dates back to 1984 gives an impression that this matter has been resisting the common fashion for regulating all the spheres of life by law, and managed to survive with minor changes despite the almost 40-year period! This situation has its strengths and weaknesses. Among the strengths one can certainly point to the framework character of the discussed regulations, due 
to which they give freedom to the organizations, leaving the founders free to regulate the internal structure of foundations in the statutes. Particularly noteworthy in this respect is the lack of detailed regulation of the most important body of a foundation - the governing board, which allows for a flexible and tailored to the needs of a particular organization method of managing its operation. Moreover, the list of possible goals and activities of foundations remains open, creating a favorable framework for the development of civil society in Poland

However, the described legal construct has an opposite side associated with difficulties that excessively general regulations may cause in practice. The very process of establishing a foundation and initiating its activity does not constitute a problem, the problems arise later. Framework, vague legal requirements that foundations are supposed to meet, e.g. in the sphere of public finance management, appear to be a legal barrier for many organizations. Lack of professional training and inability to gain external expert support often lead to liquidation of foundations. Moreover, activists are also troubled by the apparent incompatibility of regulations governing the operation of foundations with other legal acts, both those regulating the operation of NGOs, including public benefit organizations or social economy entities, and civil law regulations. Passion and good intentions alone - being the motivation to establish a non-governmental organization such as a foundation - are not enough, legal and economic knowledge is also necessary to efficiently manage a foundation.

One more disadvantageous circumstance to be mentioned is that there are very few research works concerning foundations in Poland, this topic is absolutely understudied, which results in both lack of theoretical developments concerning the possible introduction of some changes at the legislative level and in little systemic dynamics in the area of foundations' practice.

The statistical data on the non-profit sector in Poland presented in the text prove that nongovernmental organizations, despite many significant barriers, are developing dynamically. It is noteworthy that in relation to the average number of persons employed in the national economy, employment in registered non-profit organizations as of December 31, 2018 accounted for $0.9 \%$, while in relation to employment solely based on an employment relationship (employment contracts) $-1.2 \%$. If all non-governmental organizations were treated as a single employer, they would overtake all major employers in the Polish national economy.

Foundations, as structures autonomous from the state and established from below, as well as characterized by voluntary participation, are inextricably linked with the realization of socially or economically useful goals, which closely match the objectives of the state. For this reason alone, it is worth investing in the non-governmental sector, stimulating its development and supporting active entities - both by streamlining and adapting legal provisions to the changing needs and, more broadly, in a systemic dimension, by seeking for them an appropriate place and role in the political system of the state.

\section{References}

1. Blicharz J. Fundacja. Wybrane zagadnienia [A Foundation. Selected Issues]. Prace Naukowe Wydziału Prawa, Administracji $i$ Ekonomii Uniwersytetu Wrocławskiego. 2016. Issue 79. 118 p. (In Pol.).

2. Cioch H. Prawo fundacyjne [Foundation Law]. Kraków, 2007. 316 p. (In Pol.).

3. Kępa M., Podgórska-Rykała J. Prawo o fundacjach. Komentarz do ustawy o fundacjach. Działalność fundacji $w$ praktyce. Wzory dokumentów [Law on Foundations, Commentary on the Act on Foundations. The Activity of Foundations in Practice. Sample of Documents]. Warsaw: CH Beck, 2020. 201 p. (In Pol.).

4. Kępa M., Podgórska-Rykała J. Wspótpraca międzysektorowa jednostek samorzadu terytorialnego z organizacjami pozarzadowymi [CrossSectoral Cooperation of Local Government Units with Non-Governmental Organizations]. Kraków: Wydawnictwo Libron, 2020. 162 p. (In Pol.).

5. Kozłowski W. Szkice o dziejach Biblioteki Zatuskich [Drafts on the History of the Załuski Library]. Wrocław-Warsaw-Kraków-GdańskŁódź, 1986. 194 p. (In Pol.).

6. Niemirka B. Statut fundacji [The Statute of a Foundation]. Warsaw, 1995. 99 p. (In Pol.).

7. Sagan B., Strzepka J. Prawo o fundacjach. Komentarz [Law on Foundations. Commentary]. Katowice, 1992. 82 p. (In Pol.). 
8. Stomczyński A. Dom ks. Boduena 19391945 [The Priest Boudain's Home 1939-1945]. Warsaw, 1975. 231 p. (In Pol.).

9. Stecki L. Fundacja. Część pierwsza [A Foundation. The First Part]. 1996. 394 p. (In Pol.). 10. Suski P. Stowarzyszenia i fundacje [Societies and Foundations]. Warsaw, 2018. 531 p. (In Pol.).

\section{About the authors:}

Podgórska-Rykała J.

Pedagogical University of Krakow

2, Podchorążych st., Krakow, 30-084, Poland

ResearcherID: AAS-9440-2021

ORCID: 0000-0002-5723-0363

Articles in Scopus / Web of Science:

DOI: $10.35757 /$ STP.2019.47.2.2

DOI: $10.5604 / 01.3001 .0014 .1029$

DOI: 10.17072/1995-4190-2021-51-186-197

\section{Kępa M.}

Pedagogical University of Krakow

2, Podchorążych st., Krakow, 30-084, Poland

ORCID: 0000-0001-8013-0734

Articles in Scopus / Web of Science:

DOI: 10.17072/1995-4190-2021-51-186-197
11. Taubenschlag R., Kozubski W. Historia $i$ instytucje rzymskiego prawa prywatnego [History and Institutions of Roman Private Law]. Warsaw, 1947. 366 p. (In Pol.).

12. Wójcik $M$. Pojęcie i typy fundacji w prawie rzymskim [The Concept and Types of a Foundation in Roman Law]. Roczniki Nauk Prawnych. 2000. Vol. 10. Issue 1. Pp. 17-38. (In Pol.).

\section{Информация об авторах:}

\section{Подгорска-Рыкала И.}

Краковский педагогический университет 30-084, Польша, г. Краков, ул. Подхоронжих, 2

ResearcherID: AAS-9440-2021

ORCID: 0000-0002-5723-0363

Статьи в БД «Scopus» / «Web of Science»:

DOI: $10.35757 /$ STP.2019.47.2.2

DOI: $10.5604 / 01.3001 .0014 .1029$

DOI: 10.17072/1995-4190-2021-51-186-197

\section{Кемпа М.}

Краковский педагогический университет 30-084, Польша, г. Краков, ул. Подхоронжих, 2

ORCID: 0000-0001-8013-0734

Статьи в БД «Scopus» / «Web of Science»: DOI: 10.17072/1995-4190-2021-51-186-197 